\title{
The Construction of Entrepreneurship Ecosystems in American Entrepreneurial Universities
}

\author{
Wei LU ${ }^{\mathrm{a}}$, Shan-Shan LI, ${ }^{\mathrm{b},}$ \\ North China Electric Power University, Baoding 071003, Hebei, China \\ ancepulss2010@126.com, ${ }^{\mathrm{b}} 15230270250 @ 126 . c o m$
}

Keywords: entrepreneurship ecosystem; entrepreneurial university; entrepreneurship education

\begin{abstract}
Entrepreneurship education was originated in America. In recent years, with more and more attention paid to entrepreneurship education, practices of those famous American entrepreneurial universities have aroused public concern, among which includes the entrepreneurship ecosystems in American entrepreneurship education. Through case study on four entrepreneurial universities in America, it found that entrepreneurship ecosystem was made up of a large number of closely linked and complementary projects and centers, student groups and entrepreneurship curriculum, which made entrepreneurship activity and entrepreneurship education in university well-interacted and has set a great example for our universities in China.
\end{abstract}

\section{Introduction}

It is believed that entrepreneurship education started in America when Myles Mace taught the first entrepreneurship course-Management of New Enterprises-at Harvard's Business School in February 1947 which drew 188 of 600 second-year MBA students. With the development of near 70 years, American entrepreneurship education has formed a well-established system, which includes entrepreneurship ecosystem in those entrepreneurial universities. In order to uncover the secrets of entrepreneurship ecosystems and give some enlightenment for Chinese universities, this paper has made researches on four famous entrepreneurial universities in America, i.e. Harvard University, Babson College, MIT and Stanford University, and found out the components of ecosystems in those universities and their interactions.

\section{Background of the Study}

With the number of graduates from universities and colleges rising dramatically, it is more and more difficult for college students to find a job. Facing with the fierce competition in the job market, large quantities of college graduates choose to start their own business instead of becoming an employee in other companies. Under this background, many universities in China try to enhance their entrepreneurship education and practice by learning from some famous American entrepreneurial universities like the MIT and Stanford.

This thesis will give a brief introduction about entrepreneurship ecosystems in four representative American entrepreneurship universities by describing the entrepreneurship curriculum, entrepreneurship activities, student groups and some projects and centers, and try to find out the interactions between entrepreneurship activities and entrepreneurship education, hoping to provide some enlightenment for universities in China to improve the quality of entrepreneurship education and equip their students with better entrepreneurial skills.

\section{Method of the Study}

The method of case study is applied in this research, since case study is quite applicable to the process of understanding a phenomenon, looking for new concepts or ideas, and even suitable to the process of theorizing. This research has strictly followed the general principles, procedures and methods of typical case study, defining two fundamental research problems: What are basic elements of entrepreneurship ecosystem? How do those elements work with each other to promote the entrepreneurship education and entrepreneurship activities in entrepreneurial universities? 
This paper chose four representative entrepreneurial universities in America(i.e. Harvard University, Babson College, MIT and Stanford University) as research subjects, because those universities are the most successful in entrepreneurship education and choosing typical cases is the most common practice in case study.

\section{Entrepreneurship Ecosystem in Famous Entrepreneurial Universities}

\section{Entrepreneurship Ecosystem in Harvard University}

Harvard University was founded in 1639, and has become one of the most outstanding universities in the United States. Harvard Business School was established in 1908. It is believed that the first MBA project in the world as well as the first entrepreneurship course was originated here. Harvard Business School is honored as "the Garden of Eden" for entrepreneurship education in America. Entrepreneurship is defined as "the pursuit of opportunity beyond resources currently controlled" in Harvard University, which is regarded as the "best answer ever" by INC Magazine.

\section{Entrepreneurship curriculum in Harvard University}

In 2001, Harvard Business School started the first entrepreneurship course in its compulsory curriculum and after that, more and more entrepreneurial management courses appeared in the curriculum. From the resources on the website of Harvard Business School, it can be found that there are 18 courses related to entrepreneurship and enterprise management arranged for MBA students in the Fall Semester of 2016 and the Spring Semester of 2017. The most representative courses include "Entrepreneurial Finance", "Entrepreneurial Sales and Marketing", "Entrepreneurship and Global Capitalism", "Financial Management of Smaller Firms", "Law, Management and Entrepreneurship", "Venture Capital and Private Equity", etc. which teach students to transform opportunities into companies and institutions that make a difference in the world.

These entrepreneurship courses will provide students with an understanding of issues facing entrepreneurs and an exposure to the skills involved in addressing them. After taking those courses, students will be able to equip themselves with innovative and critical thinking, skills needed to create a new company, as well as theoretical framework about entrepreneurship.

\section{Entrepreneurship activities in Harvard University}

If entrepreneurship curriculum provides students with theoretical framework for creating startups, it is various kinds of entrepreneurship activities and student groups that offer opportunities for them to apply what they have learned into practice. Here are some famous entrepreneurship activities in Harvard.

New Venture Competition

The New Venture Competition which is developed from the "Business Plan Contest" since 1997 is an annual student competition sponsored by Harvard Business School's Rock Center for Entrepreneurship and Social Enterprise Initiative. It supports students and alumni launching new business and social impact ventures. The goal of the competition is to solve important problems that will advance both business and society in impactful new ways.

The competition is divided into two parts: Student Competition and Alumni Competition. Students will great ideas would work with a team and finally make a difference in the world through this competition. The final winner will get $\$ 150,000$ in cash as prize.

(2) Incubation Centers

In order to support new startups, encourage and guide students' entrepreneurial behavior, and create a sound environment for students to start up their own businesses, Harvard University established some incubation centers like the i-Lab and Startup Studio NYC, which have offered great support for the development of newly created businesses.

The Harvard Innovation Lab (i-lab) is a new initiative fostering team-based and entrepreneurial activities among Harvard students, faculty, entrepreneurs, and members of the Allston and Greater 
Boston community. The i-lab encourages entrepreneurship and innovation across the University, bringing together many cross-curricular interests. The i-lab occupies over 30,000 square feet of space that is divided into three areas: the lobby area which has a cafe and flexible seating, a multi-media presentation and lecture hall and a flex-space open area for registered i-lab residents. This i-lab is designed to foster entrepreneurship and team-based learning.

(3) Rock Accelerator Program

Rock Accelerator Program was launched by Arthur Rock Center for Entrepreneurship of Harvard University in 2010 with the goal to provide capital for high impact new ventures created by students. This innovative and competitive year long program provides $10-20$ founding teams with up to $\$ 8,000$ each in seed capital and matched mentors to support students' entrepreneurial practices.

\section{Entrepreneurship Ecosystem in Babson College}

The major provider of entrepreneurship education in America is business school and Babson College has been regarded as the best-known business college in entrepreneurship management education and research. It was founded in 1919; in 1967, it started the first entrepreneurship course for graduate students; in 1968, its entrepreneurship courses were extended to cover undergraduate students; and its Babson College Entrepreneurship Research Conference (BCERC) was established in 1979. U.S. News \& World Report has ranked Babson College No.1 in entrepreneurship for an unprecedented 19th time, which shows its significant role in American entrepreneurship education.

\section{Entrepreneurship Curriculum in Babson College}

Babson was one of the first academic institutions in the world to offer a course in entrepreneurship. Since then, it has been internationally recognized as the leader in entrepreneurship education. Entrepreneurship isn't just an academic discipline at Babson; it is a way of life.

Entrepreneurship courses in Babson can be divided into two categories: required core courses and elective courses. Important courses for undergraduate students include "Foundations of Management and Entrepreneurship", "Financial Accounting and Business Law", "Introduction to Financial Accounting", "Quantitative Methods for Business Analytics", "Principles of Microeconomics", "Strategic Problem Solving", etc. and core courses for graduate students contain "Entrepreneurship \& Opportunity", "Financial Reporting", "Market Segmentation and Price Discrimination", "Creating and Leading Effective Organizations", etc.

Through the entrepreneurship courses, Babson students learn to recognize, create and shape opportunities, provide the leadership and build the team to create economic and social value. They teach both predictive and creative approaches to all aspects of launching, growing and expanding businesses and organizations.

\section{Entrepreneurship Activities in Babson College}

(1) Business Plan Competition

Business plan competition of Babson College started in 1984, and has become a inseparable part in Babson entrepreneurship ecosystem. The competition prizes are awarded to the individual student or team that submits the most feasible business plan in any of the following areas: start-ups, acquisitions, company growth, real estate development, and entrepreneurship. A panel of judges consisting of entrepreneurs, venture capitalists, and local business people evaluates the business plans and listens to finalists' presentations.

(2) Alumni Entrepreneur Hall of Fame

Established in 2008, the hall of fame celebrates alumni who have distinguished themselves in entrepreneurial endeavors across all types of enterprises. Alumni entrepreneurs are inducted annually during a gala dinner where they are recognized for their accomplishments in creating economic and social value. "Rising Star" entrepreneurs have been honored at Babson since 2010 as part of the Alumni Entrepreneur Hall of Fame awards ceremony. These individuals have founded or co-founded businesses which are less than 10 years old, are making an impact in their marketplace and generating 
media attention. After the ceremony, those successful alumni entrepreneurs will be invited to share their experiences in starting new businesses with students.

(3) The John E. and Alice L. Butler Venture Accelerator

The John E. and Alice L. Butler Venture Accelerator at Babson provides an ecosystem where participants live and breathe entrepreneurship. Through the diverse programs, students and alumni explore opportunities and move their business concepts forward, taking advantage of workspace, peer-mentoring programs, expert advisers, and other valuable resources. The entrepreneurial community there offers unparalleled support throughout each stage of the business's development, helping students and alumni entrepreneurs stay focused as they turn their idea into a reality.

\section{Entrepreneurship Ecosystem in MIT}

Massachusetts Institute of Technology (MIT) is a world famous research university and is honored as "the best university of science and engineering in the world". The most noteworthy is that, as an outstanding research university, the MIT also makes remarkable achievements in entrepreneurship education. This leading research-based university not only educates productive workers who create value as employees of large established firms but also cultivates entrepreneurs who commercialize ideas - often research-based - and builds innovation-driven enterprises. It is estimated that, by 2014, at least 30,000 currently active companies have been founded by MIT alumni of both undergraduate and graduate programs, generating annual global revenues of $\$ 1.9$ trillion, which is roughly equivalent to he GDP of the world's $10^{\text {th }}$ largest economy as of 2014. MIT's ambitious entrepreneurship educational program rests upon three principles: (1)Mens et Manus, (2)teams, not individuals, and (3)cross-disciplinary collaboration, and forms a well-established entrepreneurship ecosystem.

\section{Entrepreneurship Curriculum in MIT}

Martin Trust Center for MIT Entrepreneurship has provided 54 entrepreneurship courses for students which can be divided into four categories: (1) general entrepreneurship courses centered on business plan, such as "New Enterprises", "Entrepreneurial Strategy", etc. (2) courses introducing professional knowledge on entrepreneurship activities, such as "Entrepreneurial Product Development and Marketing", "Entrepreneurial Finance and Venture Capital", "Essential Law for Business", "Development Ventures", "Patents, Copyrights, and the Law of Intellectual Property", etc. (3) entrepreneurship courses connected with some specific fields, such as "Medical Device Design", "Energy Ventures", "Media Ventures", "Strategic Decision Making in the Biomedical Business", "Management in Engineering", etc. (4) practice-oriented entrepreneurship courses, such as "Regional Entrepreneurial Acceleration Lab (REAL)", "Entrepreneurship Lab (E-Lab)", "Global Entrepreneurship Lab", etc.

Classes in MIT are taught not only by discipline-based academics but also by experienced, successful entrepreneurs and venture capitalists, which has generated an effective blend for learning both theory and practice and gives students the opportunity to apply the skills they have learned within the curriculum.

\section{Entrepreneurship Activities in MIT}

MIT's entrepreneurship-related student clubs and activities are diverse and ever expanding. They include:

The MIT \$100K Entrepreneurship Competition

The MIT $\$ 100 \mathrm{~K}$ is the first substantial student organization in entrepreneurship, which started in 1990 and celebrated its 25 th anniversary in 2015 with over 1,000 students participating in more than 300 teams. For many years, the competition had seven tracks for competing, judging, and awards: Energy; Life Sciences; Web/IT; Mobile; Products and Services; Emerging Markets; and Creative Arts. The first-prize winner in each track receives $\$ 50,000$. Every year, five to six new companies will be created by this competition. It is said that among the top 50 high-tech enterprises $46 \%$ are originated from the MIT $\$ 100 \mathrm{~K}$ Entrepreneurship Competition. 
(2) MIT Global Founders' Skills Accelerator (GFSA)

GFSA, initiated by Martin Trust Center Managing Director Bill Aulet, provides a three-month summer capstone educational experience to move student teams from interesting ideas and/or proofs of concept to launch-ready enterprises.

(3) MIT-China Innovation and Entrepreneurship Forum (MIT-CHIEF)

Founded in 2011 by a group of MIT students, MIT-CHIEF is committed to promoting intellectual exchanges and collaborations between China and the United States in technology, innovation and entrepreneurship. As one of the largest entrepreneur communities on the East Coast, it strives to connect the most valuable US-based startups with leading investors, strategic partners and market access in China.

\section{Entrepreneurship Ecosystem in Stanford University}

On October 1, 1891, Stanford rose from a largely undeveloped agrarian area and dedicated to the formation of "cultured and useful citizens." Stanford University is quite different from those conventional universities in the East. Without the constraint of religion and tradition, Stanford always pursues practical technology. The pioneering spirit and risk-taking culture of old generations in Stanford have made Stanford University one of the best in entrepreneurship education and practice.

\section{Entrepreneurship Curriculum in Stanford University}

In 1967, the first contemporary MBA entrepreneurship courses were introduced at Stanford. In 1996, Stanford Business School set up the Entrepreneurship Study Center, and in 1990s, it established E-Commerce \& E-Business Center to adapt to the Internet Age. Now, Stanford has established many research centers related to entrepreneurship and innovation. Apart from the Business School, School of Engineering and School of Medicine in Stanford also offer entrepreneurship courses.

Entrepreneurship management courses in Stanford have been separated into nine categories: Experiential Courses, Building a Team \& Scaling, Computing, Finance \& Funding, Legal Frameworks, Marketing \& Sales, Product Design \& Manufacturing, Search Funds and Startup Foundations. There are corresponding courses under each category. These courses are provided not only by Business School, but also by all of the seven existing schools in Stanford University, which shows inter-disciplinary cooperation. Apart from those theoretical courses, Stanford also offers an intensive hands-on, project-based course named Startup Garage in which students design and test new business concepts that address real-world needs.

\section{Entrepreneurship Activities in Stanford University}

(1) Stanford Venture Studio

The Stanford Venture Studio is an entrepreneurial hub and a collaborative learning community for students across all disciplines and at any stage of entrepreneurship. It provides a supportive environment including space, facilities, advisers and training for students to learn entrepreneurship or start up their venture.

(2) BASES \$100k Startup Challenge

The Business Association of Stanford Entrepreneurial Students (BASES) is at the heart of student entrepreneurship at Stanford University. As one of the oldest student-run entrepreneurship organizations in the world, BASES promotes entrepreneurship education at Stanford University in order to empower the next generation of entrepreneurs. Programs organized by BASES include the BASES \$100k Startup Challenge, Entrepreneurial Thought Leaders' Seminar, Startup Career Fair, Women in Entrepreneurship Summit, and Social Impact Week.

BASES Challenge is Stanford's oldest and most competitive annual entrepreneurship competition. Students and alumni enter their business or social venture ideas to compete for $\$ 100,000$ in prize money and developmental opportunities. 


\section{Conclusion}

After studying the entrepreneurship ecosystem in four representative entrepreneurial universities in America, the study has found that entrepreneurship ecosystem is usually made up of a large number of closely linked and complementary projects and centers, student groups and entrepreneurship curriculum, which made entrepreneurship activity and entrepreneurship education in university well-interacted. Entrepreneurship curriculum will teach students some basic theoretical approaches to all aspects of launching, growing and expanding new businesses; entrepreneurship activities will offer students opportunities to apply theories into practice; various centers will provide institutional and legal support for students' entrepreneurship, which provides great experience for China to learn.

\section{References}

[1] Edward B. Roberts, Fiona Murray, and J. Daniel Kim. Entrepreneurship and Innovation at MIT: Continuing Global Growth and Impact[R]. Boston: Massachusetts Institute of Technology, 2015.

[2] https://entrepreneurship.hbs.edu/faculty-and-courses/Pages/mba-and-doctoral-courses.aspx

[3] https://entrepreneurship.mit.edu/academics-fall2015

[4] https://entrepreneurship.mit.edu/ecosystem-competitions-programs

[5] http://www.babson.edu/Academics/divisions/entrepreneurship/curriculum/Pages/home.aspx

[6] http://www.gsb.stanford.edu/faculty-research/centers-initiatives/ces

[7] Jerome A. Katz. The chronology and intellectual trajectory of American entrepreneurship education 1876-1999[J]. Journal of Business Venturing, 2003(18):283-300.

[8] Liu Linqing et al. On Entrepreneurship Ecosystem of Entrepreneurial University: A Case Study of MIT[J]. Journal of Higher Education, 2009(3):19-26.

[9] Rock Accelerator Program [EB/OL]. https://entrepreneurship.hbs.edu/programs/Pages/rock-accelerator-program.aspx

[10] The Harvard Innovation Lab [EB/OL]. https://en.wikipedia.org/wiki/Harvard_innovation_lab 